\title{
Effect of R-plasmid RP1 on Surface Hydrophobicity of Proteus mirabilis
}

\author{
By JOSIAH A. ONAOLAPO AND RUTH M. M. KLEMPERER* \\ Microbiology Research Group, Department of Pharmaceutical Sciences, Aston University, \\ Aston Triangle, Birmingham B4 7ET, UK
}

(Received 16 December 1985; revised 24 July 1986)

The presence of R-plasmid RP1, as well as the conditions of growth, affected the surface
hydrophobicity of a clinical isolate of Proteus mirabilis. However, results depended upon the
method of assessment. Stationary phase plasmid-containing cells appeared to be less
hydrophobic than plasmid-free cells when hydrophobicity was measured by the contact angle
method, but more hydrophobic when measured by bacterial adherence to hydrocarbons or
hydrophobic interaction chromatography. Cells growing in a chemostat differed in hydrophobi-
city from stationary phase cells and results varied with the growth rate. Plasmid-mediated
effects were greatest in iron-depleted cells, and differences between plasmid-containing and
plasmid-free cells were virtually eliminated by pre-treatment with antiserum.

\section{INTRODUCTION}

Many surface properties contribute to pathogenicity (Smith, 1977). In particular, hydrophobic interactions have been implicated in adhesion (Rosenberg et al., 1983) and phagocytosis (Van Oss, 1978). Plasmid RP1 has previously been reported as affecting cell envelope properties (Curtis \& Richmond, 1974; Klemperer et al., 1980), and plasmid RP4, which shares much of its genome with plasmid RP1 (Saunders \& Grinsted, 1972), increases the hydrophobicity of laboratory strains of Escherichia coli (Ferreirós \& Criado, 1984) when measured by bacterial adherence to hydrocarbons (BATH) or salting out.

Here we report the effect of RP1 on the surface properties of a clinical isolate of Proteus mirabilis, as assessed by contact angle measurements, BATH and hydrophobic interaction chromatography (HIC). The effects of growth under a variety of environmental conditions, and of treatment with normal and immune sera, were also investigated.

\section{METHODS}

Cultures. Proteus mirabilis PB13 (a motile, but non-swarming isolate from a patient with a urinary tract infection) was obtained from Ninewells Hospital, Dundee, UK, and R-plasmid RP1, from Dr E. J. L. Lowbury, The Accident Hospital, Birmingham, UK, was transferred to it (Meynell \& Meynell, 1970). Stock cultures were maintained on nutrient agar (NA) and the presence of the plasmid was checked by plating on NA containing ampicillin $\left(25 \mu \mathrm{g} \mathrm{ml}^{-1}\right)$. The plasmid was stable under all conditions. Cells, with $\left(\mathbf{R}^{+}\right)$and without $\left(\mathbf{R}^{-}\right) \mathbf{R P I}$, were grown at $37^{\circ} \mathrm{C}$ in a simple salts medium at $\mathrm{pH} 7 \cdot 0$, aerated by shaking in conical flasks (batch culture) or by bubbling air through $50 \mathrm{ml}$ chemostats (Gilbert \& Stuart, 1977) at $35 \mathrm{~cm}^{3} \mathrm{~min}^{-1}$ (continuous culture). The medium contained the following compounds, all at concentrations at least ten times in excess of requirements: glucose (40 mM), $\mathrm{MgSO}_{4}(0.2 \mathrm{mM}), \mathrm{NH}_{4} \mathrm{SO}_{4}(0.2 \mathrm{~mm}), \mathrm{FeSO}_{4}(0.005 \mathrm{mM}), \mathrm{NH}_{4} \mathrm{H}_{2} \mathrm{PO}_{4} /\left(\mathrm{NH}_{4}\right)_{2} \mathrm{HPO}_{4}$ buffer (100 mM), $\mathrm{KCl}(30 \mathrm{~mm}), \mathrm{NaCl}(0.1 \mathrm{~mm})$ and nicotinic acid (0.06 mM) (all Analar grade in double-distilled water). Osmolarity was equivalent to that of $0.85 \%$ saline. These cultures were assumed to be oxygen-depleted when stationary. The concentration of glucose was reduced to $4 \mathrm{mM}$ for carbon-depleted batch cultures and to $3 \mathrm{~mm}$ for carbon-limited continuous cultures; for iron-limited cultures, iron was omitted and the phosphate buffer was passed once before

Abbreviations: $\mathrm{R}^{+}$cells, RP1-containing cells; $\mathrm{R}^{-}$cells, RP1-free cells; BATH, bacterial adherence to hydrocarbons; HIC, hydrophobic interaction chromatography. 
use through a column of Chelex-100 iron exchange resin (Bio-Rad). To ensure that cultures were depleted or limited as described, the relation between cell mass and various growth conditions was determined (Cozens et al., 1983).

Surface hydrophobicity. This was assessed by three methods. Contact angles were measured as described by Van Oss (1978), using $10 \mu \mathrm{l}$ drops of $0.85 \% \mathrm{NaCl}$ on a dried pad of cells $\left(20 \mathrm{ml}, \mathrm{OD}_{470}=10\right.$, washed twice in $\left.\mathrm{NaCl}\right)$ on a $45 \mathrm{~mm}$ cellulose acetate membrane filter (Millipore). BATH was measured as described by Rosenberg (1984). Cells were washed twice in phosphate/urea/Mg (PUM) buffer $\mathrm{pH} 7 \cdot 1$, resuspended in PUM buffer at $\mathrm{OD}_{470}=1.0$ and vortexed with various volumes of hydrocarbon. The $\mathrm{OD}_{470}$ of the aqueous phase was expressed as a percentage of the $\mathrm{OD}_{470}$ of a standard volume of untreated cells. HIC was measured as described by Smyth $e t$ al. (1978), using octyl- or phenyl-Sepharose CL-4B (Pharmacia) washed several times with distilled water and then with various concentrations of $\mathrm{NaCl}$ buffered with $0.01 \mathrm{M}$-phosphate buffer $\mathrm{pH} 7.0$; cells were washed two times in the same buffer and resuspended at $\mathrm{OD}_{470}=5$. The same buffer used to wash the column and cells was used to elute cells from the column. The $\mathrm{OD}_{470}$ of the eluate from hydrophobic Sepharose was expressed as a percentage of the $\mathrm{OD}_{470}$ of the eluate from Sepharose with no ligand attached.

Removal of surface appendages. This was done by vortexing cultures in a domestic blender (Kenwood Deluxe) at maximum speed for $10 \mathrm{~s}$. Cells were then washed in the same way as the equivalent unblended cells. The presence of flagellar proteins in the supernatant was checked by SDS-PAGE (Montie \& Stover, 1983).

Antisera. These were prepared by inoculating rabbits subcutaneously with $0.2 \mathrm{ml}$ of a suspension of stationary phase, iron-depleted cells, washed twice and resuspended in $0.85 \%$ saline $\left(10^{9}\right.$ cells $\left.\mathrm{ml}^{-1}\right)$, at weekly intervals for 4 months and bleeding after 1 week. Blood was allowed to clot and was centrifuged briefly. The titre against homologous cells measured by tube agglutination was $1: 1920$ for antisera against both $\mathbf{R}^{+}$and $\mathbf{R}^{-}$cells. Sera from two rabbits for each batch of cells were tested independently. Normal sera from the same rabbits were prepared before immunization commenced. Complement was inactivated, when necessary, by heating at $56{ }^{\circ} \mathrm{C}$ for $30 \mathrm{~min}$.

To test the effect of sera on hydrophobicity measured by BATH, cells were washed once in PUM buffer, incubated with $10 \%$ serum in PUM buffer at $37^{\circ} \mathrm{C}$ for $15 \mathrm{~min}$, washed twice in PUM buffer, resuspended in the buffer at $\mathrm{OD}_{470}=1.0$ and vortexed with various volumes of hydrocarbon.

\section{RESULTS}

\section{Effect of plasmid RPI on the hydrophobicity of stationary phase cells}

When hydrophobicity was determined by contact angles, $\mathbf{R}^{+}$cells, particularly when oxygendepleted, were less hydrophobic than $\mathrm{R}^{-}$cells (Table 1 ). Following brief treatment in a blender to remove surface appendages, the hydrophobicity of all cells was reduced. However, $\mathrm{R}^{+}$cells remained less hydrophobic than $\mathrm{R}^{-}$ones, oxygen- and iron-limited ones being particularly hydrophilic.

Using HIC or BATH, the opposite results were obtained, and blending had no significant effect. HIC appeared to be the more sensitive method of measurement and differences between cells was greater. Significant plasmid-mediated effects were found for iron- or oxygen-depleted cells by HIC (Fig. 1) and for iron-depleted cells by BATH.

Treatment with normal rabbit serum increased the hydrophobicity of iron-depleted $\mathrm{R}^{-}$cells, but had little effect on $\mathrm{R}^{+}$ones, when measured by BATH (Fig. 2). Similar results were obtained with carbon-depleted cells, and with both sets of cells using normal guinea-pig serum. Heatinactivated normal sera had little effect on any cells.

Treatment with heat-inactivated homologous antiserum also increased the hydrophobicity of iron-depleted $\mathrm{R}^{-}$cells, but had little effect on $\mathrm{R}^{+}$cells. However, untreated homologous

\section{Table 1. Contact angles of $R^{+}$and $R^{-}$stationary phase cultures of Proteus mirabilis}

Cultures were incubated overnight in batch culture. Results are means \pm SD of four determinations.

\begin{tabular}{|c|c|c|c|c|}
\hline \multirow[b]{2}{*}{ Culture } & \multicolumn{2}{|c|}{$\mathrm{R}^{-}$cells } & \multicolumn{2}{|c|}{$\mathbf{R}^{+}$cells } \\
\hline & Untreated & Blended* & Untreated & Blended* \\
\hline $\begin{array}{l}\mathrm{O}_{2} \text {-limited } \\
\mathrm{C} \text {-limited } \\
\text { Fe-limited }\end{array}$ & $\begin{array}{l}40 \cdot 5 \pm 1.8 \\
34 \cdot 0 \pm 1.6 \\
39 \cdot 2 \pm 2 \cdot 1\end{array}$ & $\begin{array}{l}21.9 \pm 0.8 \\
23.4 \pm 2.3 \\
20.8 \pm 0.52\end{array}$ & $\begin{array}{l}20.9 \pm 2.3 \\
28.1 \pm 1.9 \\
35.4 \pm 2.1\end{array}$ & $\begin{array}{l}15.3 \pm 1.2 \\
21.9 \pm 2.0 \\
16.7 \pm 0.76\end{array}$ \\
\hline
\end{tabular}

* Flagellar protein was detected in the supernatant after this treatment. 


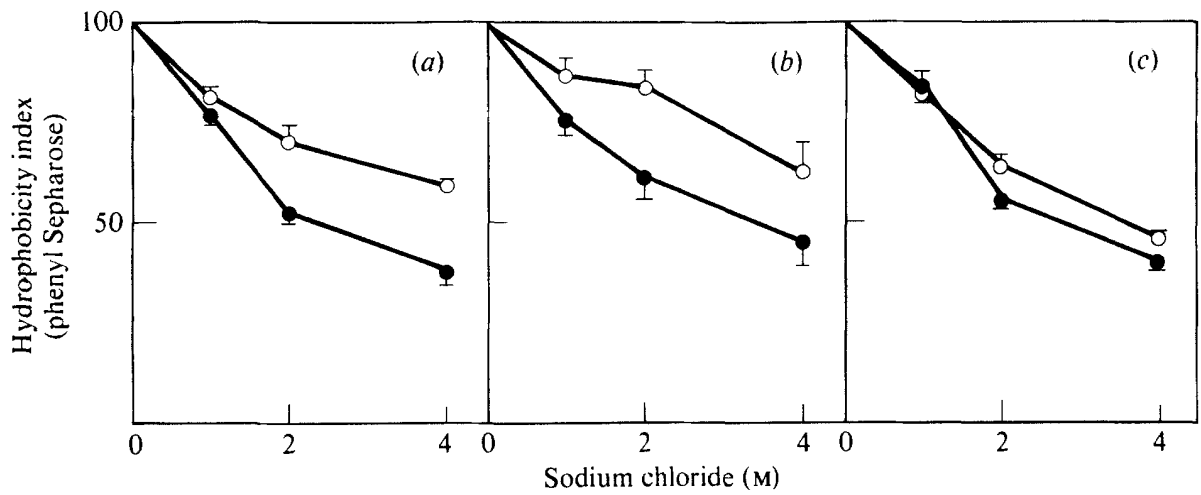

Fig. 1. Surface hydrophobicity, measured by HIC with phenyl Sepharose, of iron-depleted (a), oxygendepleted $(b)$ or carbon-depleted $(c)$ stationary phase $\mathrm{R}^{+}(\mathbf{O})$ or $\mathbf{R}^{-}(\mathrm{O})$ Proteus mirabilis cells. Hydrophobicity index (phenyl Sepharose) is the $\mathrm{OD}_{470}$ of the eluate from phenyl Sepharose expressed as a percentage of the $\mathrm{OD}_{470}$ of the eluate from Sepharose (NB the hydrophobicity is greatest when the index is smallest). Results are means of four experiments; bars indicate SD. Similar results were obtained using octyl Sepharose.

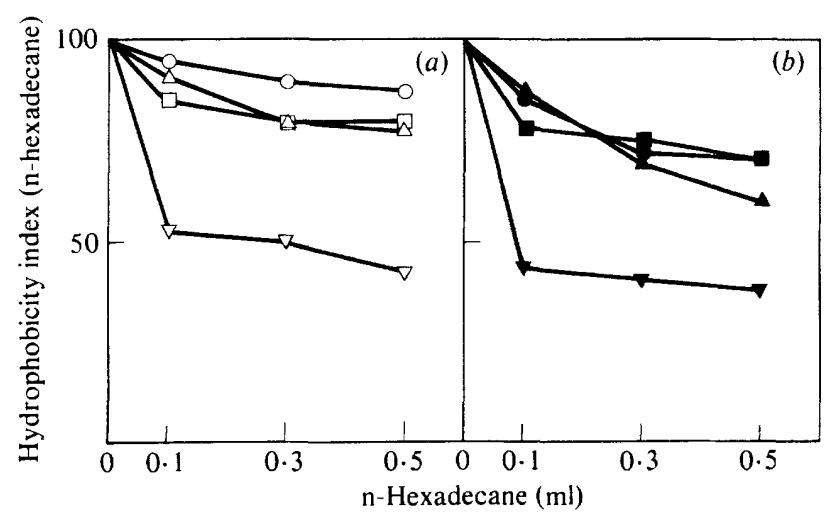

Fig. 2. Surface hydrophobicity, measured by BATH with $\mathrm{n}$-hexadecane, of iron-depleted $\mathbf{R}^{-}(a)$ or $\mathbf{R}^{+}$ (b) Proteus mirabilis cells. Cells were untreated $(O, O)$ or treated with normal serum $(\square, \square)$, heatinactivated immune serum $(\boldsymbol{\Lambda}, \Delta)$ or fresh immune serum $(\nabla, \nabla)$. Hydrophobicity index (n-hexadecane) is the $\mathrm{OD}_{470}$ of the aqueous layer after vortexing with $\mathrm{n}$-hexadecane as a percentage of the $\mathrm{OD}_{470}$ of the aqueous layer of the untreated cell suspension (NB the hydrophobicity is greatest when the index is smallest). Results are representative of two experiments with two rabbits. Similar results were obtained using n-octane.

antiserum markedly increased the hydrophobicity of both cell suspensions, and differences between then were eliminated (Fig. 2).

\section{Effect of plasmid RPI on the hydrophobicity of chemostat cultures}

Only small differences were detectable between $\mathrm{R}^{+}$and $\mathrm{R}^{-}$cells grown in a chemostat as measured by BATH. However, using HIC, considerable differences were found and, contrary to stationary phase cells, $\mathrm{R}^{+}$cells were less hydrophobic than $\mathbf{R}^{-}$cells. As growth rate increased, cells became more hydrophobic. Iron-limited cells were more hydrophobic than carbon-limited ones in all cases (Fig. 3).

\section{DISCUSSION}

Many cell properties have been attributed to surface hydrophobicity, but the contradictory results reported here indicate the importance of only comparing data that are obtained by the same methods of assessment. 


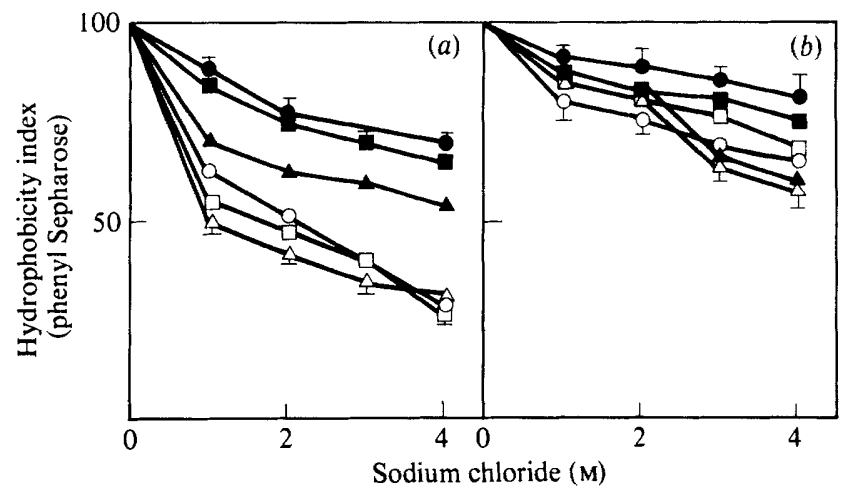

Fig. 3. Surface hydrophobicity, measured by HIC using phenyl Sepharose, of iron-limited (a) or carbon-limited $(b)$ chemostat-grown $\mathbf{R}^{+}(\mathbf{O}, \mathbf{Q}, \mathbf{\Delta})$ or $\mathbf{R}^{-}(O, \square, \triangle)$ Proteus mirabilis cells at dilution rates of $0.1 \mathrm{~h}^{-1}(\mathcal{O}, 0), 0.2 \mathrm{~h}^{-1}(\square, \square)$ and $0.4 \mathrm{~h}^{-1}(\Lambda, \triangle)$. Hydrophobicity index (phenyl Sepharose) is defined in Fig. 1. Results are means of four experiments; bars indicate SD. Similar results were obtained with octyl Sepharose.

Contact angles may indicate the most superficial properties; these were the only results that were affected by blending. Removal of surface appendages (probably mainly flagella, which are unlikely to interfere in vivo) reduced the contact angles of some $\mathrm{R}^{+}$cells (iron- or oxygendepleted) to less than $18^{\circ}$, the critical figure below which phagocytosis by human polymorphonuclear leucocytes becomes impeded (Van Oss, 1978). Using HIC, in which surface charge is greatly reduced by $\mathrm{NaCl}$, the results were reversed, and iron and oxygen depletion resulted in the biggest differences between $\mathrm{R}^{+}$and $\mathrm{R}^{-}$cells. Using BATH, which is thought to reflect interactions with the core regions of LPS (Rosenberg et al., 1980) or membrane phospholipids (Rosenberg et al., 1982), similar, but smaller differences, were obtained. These may be of importance in virulence, because an increase in hydrophobicity as measured by BATH has been correlated with adhesion to animal cells for both Gram-positive and Gramnegative species (Rosenberg et al., 1983). Plasmid RPl encodes a rigid constitutive pilus (Bradley, 1983), which might be expected to increase hydrophobicity as determined by HIC (Tewari et al., 1985).

Changes in the cell envelope with nutrient availability (Brown \& Williams, 1985) and growth phase (Cronan et al., 1974) are well known, and the increase in surface hydrophobicity with increase in growth rate is similar to that reported for Pseudomonas putida, when assessed by HIC (Nilsson \& Dostálek, 1984). The big effect of RP1 on iron-limited cells is of particular interest, as cells are probably iron-limited in vivo (Weinberg, 1984). However, the differences between $\mathrm{R}^{+}$ and $\mathrm{R}^{-}$cells were negligible after treatment with normal or immune serum.

Josiah A. Onaolapo acknowledges with thanks a Commonwealth Scholarship.

\section{REFERENCES}

BradLey, D. E. (1983). Specification of the conjugative pili and surface mating systems of Pseudomonas plasmids. Journal of General Microbiology 129, 25452556.

Brown, M. R. W. \& Williams, P. (1985). The influence of environment on envelope properties affecting survival of bacteria in infections. Annual Review of Microbiology 39, 527-556.

Cozens, R. M., Klemperer, R. M. M. \& Brown, M. R. W. (1983). The influence of cell envelope composition on antibiotic activity. In Antibiotics: Assessment of Antimicrobial Activity and Resistance, pp. 61-75. Edited by A. D. Russell \& L. B. Quesnel. London: Academic Press.

Cronan, J. E., NunN, W. D. \& Batchelor, J. G. (1974). Studies on the biosynthesis of cyclopropane fatty acids in Escherichia coli. Biochimica et biophysica acta 348, 63-75.

Curtis, N. A. C. \& Richmond, M. H. (1974). Effect of R-factor mediated genes on surface properties of Escherichia coli. Antimicrobial Agents and Chemotherapy 6, 666-671.

Ferreirós, C. M. \& Criado, M. T. (1984). Expression of surface hydrophobicity encoded by R-plasmids in 
Escherichia coli laboratory strains. Archives of Microbiology 138, 191-194.

GilberT, P. \& STUART, A. (1977). Small scale chemostat for the growth of mesophilic and thermophilic microorganisms. Laboratory Practice 26, 627628.

Klemperer, R. M. M., Ismail, N. T. A. J. \& Brown, M. R. W. (1980). Effect of R-plasmid RP1 and nutrient depletion on the resistance of Escherichia coli to cetrimide, chlorhexidine and phenol. Journal of Applied Bacteriology 48, 349-357.

Meynell, G. G. \& Meynell, E. (1970). Theory and Practice in Experimental Bacteriology, 2nd edn. Cambridge: Cambridge University Press.

MoNTIE, T. C. \& Stover, G. B. (1983). Isolation and characterisation of flagellar preparations from Pseudomonas species. Journal of Clinical Microbiology 18, 452-456.

Nilsson, I. \& Dostálex, M. (1984). Estimation of the biofilm formation ability of Pseudomonas putida in discrete samples from continuous culture. Applied Microbiology and Biotechnology 30, 183-188.

RosenberG, M. C. (1984). Bacterial adherence to hydrocarbons: a useful technique for studying cell surface hydrophobicity. FEMS Microbiology Letters 22, 289-295.

Rosenberg, M., Gutnick, D. \& Rosenberg, E. (1980). Adherence of bacteria to hydrocarbons: a simple method for measuring cell-surface hydrophobicity. FEMS Microbiology Letters 3, 29-33.

Rosenberg, M., Rotrem, S. \& RosenberG, E. (1982).
Cell surface hydrophobicity of smooth and rough Proteus mirabilis as determined by adherence to hydrocarbons. FEMS Microbiology Letters 13, 167169.

Rosenberg, M., Rosenberg, E., Judes, H. \& Weiss, E. (1983). Bacterial adherence to hydrocarbons and to surfaces in the oral cavity. FEMS Microbiology Letters 20, 1-5.

SAUnders, J. R. \& Grinsted, J. (1972). Properties of RP4 an R-factor which originated in Pseudomonas aeruginosa S8. Journal of Bacteriology 112, 690-696.

SMIrH, H. (1977). Microbial surfaces in relation to pathogenicity. Bacteriological Reviews 41, 475500.

Smyth, C. J., Jonsson, P., Olsson, E., Soderlind, O., Rosengren, J., Hierten, S. \& Wadstrom, T. (1978). Differences in hydrophobic surface characteristics of porcine enteropathogenic Escherichia coli with or without $\mathrm{K} 88$ antigen as revealed by hydrophobic interaction chromatography. Infection and Immunity 22, 462-472.

Tewari, R., Smith, D. G. \& RowbURy, R. J. (1985). Effect of ColV plasmids on the hydrophobicity of Escherichia coli. FEMS Microbiology Letters 29, 245249.

VAN Oss, C. J. (1978). Phagocytosis as a surface phenomenon. Annual Review of Microbiology 32, 1939.

WEINBERG, E. D. (1984). Iron withholding: a defence against infection and neoplasia. Physiological Reviews 64, 65-74. 